\title{
PERBANDINGAN DETEKSI PROLIFERASI SEL DENGAN IMUNOHISTOKIMIA PCNA DAN BrdU PADA PANKREAS TIKUS
}

\section{EVALUATION OF CELL PROLIFERATION IN RAT PANCREAS WITH PCNA AND BrdU IMMUNOHISTOCHEMISTRY}

\author{
David Pakaya $^{1}$, Wiwit Setyowati ${ }^{2}$, Rina Susilowati ${ }^{2}$ \\ ${ }^{1}$ Departemen Histologi Fakultas Kedokteran Universitas Tadulako, Palu \\ ${ }^{2}$ Departemen Histologi Fakultas Kedokteran, Kesehatan Masyarakat dan Keperawatan Universitas Gadjah \\ Mada, Yogyakarta \\ Korespondensi: dr. David Pakaya, M.Biomed. Email: david_pakaya@untad.ac.id
}

\begin{abstract}
ABSTRAK
Pankreas merupakan jaringan labil karena terdiri dari sel-sel asinar yang selalu berproliferasi sepanjang hidupnya untuk menggantikan sel yang rusak. Proliferasi tersebut dapat diidentifikasi dengan pemeriksaan histologis, yaitu mikroteknik dengan pewarnaan imunohistokmia (IHC). Penelitian ini bertujuan untuk membandingkan deteksi proliferasi sel dengan IHC anti-PCNA dan anti-BrdU pada pankreas. Tikus diinjeksi BrdU secara intraperitoneal sebanyak 4 kali dengan selang waktu 3 jam dengan dosis BrdU 0,125 ml, 0,375 ml, 0,250 ml, dan $0,250 \mathrm{ml}$ dan dibiarkan selama 1 malam. Jaringan pankreas dipotong sepanjang $\pm 5 \mathrm{~mm}$ dan direndam dalam fiksatif paraformaldehid 4\%, kemudian dibuat blok paraffinnya. Blok parafin diiris dengan ketebalan $6 \mu m$ untuk pengecatan hematoksilin eosin (HE) dan $4 \mu$ m untuk pengecatan IHC. Pengecatan IHC dengan antibodi anti PCNA (antibodi monoklonal PCNA 1;1000 dalam PBS). Pengecatan IHC dengan antibodi anti BrdU menggunakan antibodi primer (antibodi anti BrdU 1:1000). Pengecatan dianalisis secara kualitatif. IHC menggunakan antibodi anti-PCNA dan anti-BrdU menunjukkan adanya penyebaran warna coklat gelap yang menandakan proliferasi sel aktif, dimana sel yang terekspresi pada BrdU lebih sedikit dibandingkan PCNA. Penelitian ini menyimpulkan bahwa proliferasi sel pankreas dapat terekspresi melalui perwarnaan IHC dengan antibodi anti PCNA dan anti BrdU.
\end{abstract}

Kata kunci: Imunohistokimia, PCNA, Brdu, Proliferasi

\section{ABSTRACT}

The pancreas is a labile tissue because it consists of acinar cells which proliferate throughout their lives to replace damaged cells. The proliferation can be identified by histological examination, that is microtechnics with immunohistochmia (IHC) staining. This study aims to compare the detection of cell proliferation with anti-PCNA and anti-BrdU IHC in the pancreas. The rats were injected BrdU intraperitoneally 4 times with an interval of 3 hours with a dose of BrdU $0.125 \mathrm{ml}, 0.375 \mathrm{ml}, 0.250 \mathrm{ml}$, and $0.250 \mathrm{ml}$ and left for 1 night. Pancreatic tissue were necropsy along $\pm 5 \mathrm{~mm}$ and soaked in $4 \%$ paraformaldehyde fixative, then made paraffin block. The paraffin block was sliced to a thickness of $6 \mu \mathrm{m}$ for hematoxylin eosin (HE) and $4 \mu \mathrm{m}$ for IHC painting. IHC used anti PCNA antibodies (PCNA monoclonal antibody 1; 1000 in PBS) and anti BrdU antibodies (anti BrdU primary antibodies 1: 1000). Staining was analyzed qualitatively. IHC with anti-PCNA and anti-BrdU antibodies showed the spread of dark brown which indicates active cell proliferation, whereas cells expressed in BrdU are less than PCNA. This study concluded that pancreatic cell proliferation can be expressed through the coloring of IHC with anti-PCNA and anti-BrdU antibodies.

Keyword: Immunohistochemistry, PCNA, Brdu, Proliferation

How To Cite: Pakaya, D., Setyowati, W., \& Susilowati, R. (2020). PERBANDINGAN DETEKSI PROLIFERASI SEL DENGAN IMUNOHISTOKIMIA PCNA DAN BrdU PADA PANKREAS TIKUS. Biomedika, 12(2), 98-106 doi:https://doi.org/10.23917/biomedika.v12i2.10641

DOI: https://doi.org/10.23917/ biomedika.v12i2.10641 
PENDAHULUAN

Proliferasi sel merupakan siklus pembelahan sel, sel tumbuh, mereplikasi DNAnya, dan kemudian membagi menjadi dua sel anak (Albert et al., 2010). Siklus sel ini terbagi menjadi 4 fase yaitu G1 (presintesis), S (sintesis DNA), G2 (premitosis), M (mitosis) (Albert et al., 2010; Kumar et al., 2014). Proliferasi sel dikontrol oleh sinyal dari lingkungan mikro, baik yang menstimuli maupun menghambat proliferasi tersebut. Jaringan tubuh dibagi menjadi tiga kelompok berdasarkan aktifitas proliferasinya, yaitu: 1) jaringan labil yang terus-menerus membelah. 2) jaringan stabil yang berada dalam keadaan normal, 3) jaringan permanen yang tidak membelah yaitu sel-sel yang meninggalkan siklus sel dan tidak mengalami pembelahan mitosis pada postnatal kehidupan (Kumar et al., 2014).

Pankreas merupakan jaringan labil, sel-sel asinar selalu berproliferasi sepanjang hidupnya untuk menggantikan sel-sel yang rusak. Untuk mengidentifikasi proliferasi tersebut diperlukan pemeriksaan histologis dengan mikroteknik menggunakan pewarnaan imunohistokmia (IHC) (Yin et al., 2014). Aktifitas tersebut dapat diamati dengan adanya ikatan antigen dan antibodi yang

sangat spesifik. Melalui IHC dapat memvisualisasikan letak protein spesifik dan bukan hanya protein dengan aktivitas enzimatik (Mescher, 2013).

Proliferating cell nuclear antigen (PCNA) merupakan suatu siklin yang berkarakter sebagai sliding clamp, berfungsi sebagai suatu faktor progressivitas. 5-Bromo-2'-Deoxyuridine (BrdU) merupakan analog sintetik dari timidin yang dimasukkan ke dalam DNA selama fase $\mathrm{S}$ dari siklus sel. Keduanya digunakan sebagai penanda adanya proliferasi sel. Hal ini dipengaruhi karena PCNA berperan sebagai sliding clamp akan membentuk gulungan yang mampu berinteraksi dengan protein-protein lain yang terlibat dalam replikasi DNA, dan BrdU cepat berasimilasi dengan sel-sel yang berproliferasi (Maga and Hübscher, 2003; Muskhelishvili et al, 2003). Penelitian ini bertujuan untuk melihat struktur histologis pankreas dan membandingkan deteksi proliferasi sel dengan IHC menggunakan antibody anti PCNA dan antibody anti BrdU. 


\section{METODE}

\section{Perlakuan Hewan coba}

Hewan coba yang digunakan adalah 1 ekor tikus betina galur Wistar, usia 3 minggu, berat badan 250 gram, dari Laboratorium Hewan Coba Fakultas Farmasi UGM. Tikus ditimbang, dan disuntikan BrdU secara intraperitoneal sebanyak 4 kali pada area yang berbeda dengan selang waktu 3 jam. Pertama, dengan dosis BrdU $0,125 \mathrm{ml}, \mathrm{ke}-2,0,375 \mathrm{ml}, \mathrm{ke}-30,250 \mathrm{ml}$, terakhir 0,250 $\mathrm{ml}$ dan dibiarkan selama 1 malam. Metode ini merupakan hasil pengoptimuman pewarnaan BrdU secara in vivo yang digunakan di laboratorium Histologi FKKMK UGM.

\section{Perfusi dan Nekropsi}

Tikus dianestesi terlebih dahulu sebelum nekropsi, dengan Chloral hydrate sebanyak $1 \mathrm{ml}$ secara intraperitoneal. Tikus diletakkan pada bak paraffin, dimulai proses perfusi transcardial dengan PBS dialirkan selama 5 menit dan paraformaldehid 4\% selama 15 menit. Setelah tikus terfiksasi sempurna kemudian di ambil jaringan pankreas dipotong sepanjang $\pm 5 \mathrm{~mm}$ dan dicuci dengan $\mathrm{NaCl} 0,9 \%$, selanjutnya jaringan direndam dalam wadah yang berisi larutan fiksatif paraformaldehid $4 \%$.

\section{Pembuatan blok parafin dan Pengecatan}

Sampel pankreas dibuat blok paraffin. Pengirisan dilakukan dengan mikrotom putar, untuk setiap pengecatan dibuat 3 irisan. Blok parafin diiris dengan ketebalan $4 \mu \mathrm{m}$ untuk pengecatan IHC. Pengecatan IHC dengan antibodi anti PCNA menggunakan antibodi primer (antibodi monoklonal PCNA 1;1000 dalam PBS) yang diinkubasi selama 10 menit. Pengecatan IHC dengan antibodi anti BrdU menggunakan antibodi primer (antibodi anti BrdU 1;1000) yang diinkubasi overnight, pada suu ruang. Seluruh kontrol negatif adalah jaringan pankreas yang hanya diberikan larutan PBS (Kumar and Lars, 2009).

\section{Pengamatan}

Pengamatan dilakukan dengan mikroskop cahaya Olympus CX21 yang terhubung dengan kamera digital. Foto dibuat dengan Software "Optilab". Jaringan akan dianalisis secara kualitatif. Pada Pankreas akan diamati sel-sel asinus, sel yang berproliferasi akan menunjukkan warna coklat. 
HASIL DAN PEMBAHASAN

\section{Gambaran proliferasi sel dengan PCNA}

Pengecatan IHC merupakan suatu metode pewarnaan jaringan yang digunakan untuk mendeteksi adanya suatu antigen atau antibodi pada sel atau jaringan, melaui reaksi imunologik dan kimiawi. Reaksi imunologik IHC ditandai dengan adanya reaksi antara antigen dan antibodi.

Sedangkan reaksi kimiawi ditandai dengan adanya reaksi enzimatik antara enzim dan substrat.

Pengamatan dilakukan dengan menggunakan 3 sediaan jaringan histologis yaitu (1) kontrol negatif berupa jaringan pankreas dengan PBS tanpa anti-PCNA, (2) kontrol positif berupa jaringan kolon dengan antibodi antiPCNA, dan (3) sampel berupa jaringan pankreas dengan anti-PCNA. Pengecatan dengan metode indirect IHC menggunakan antibodi primer (antiPCNA) dan sekunder (trekki universal link) yang dilabel dengan biotin. Pewarnaan label dengan betazoid $\mathrm{DAB}$ memberikan citra coklat gelap untuk mempermudah pengamatan dengan mikroskopis. Berdasarkan gambaran struktur histologis sel yang aktif berproliferasi memberikan warna coklat gelap seperti yang tampak pada gambar 2.

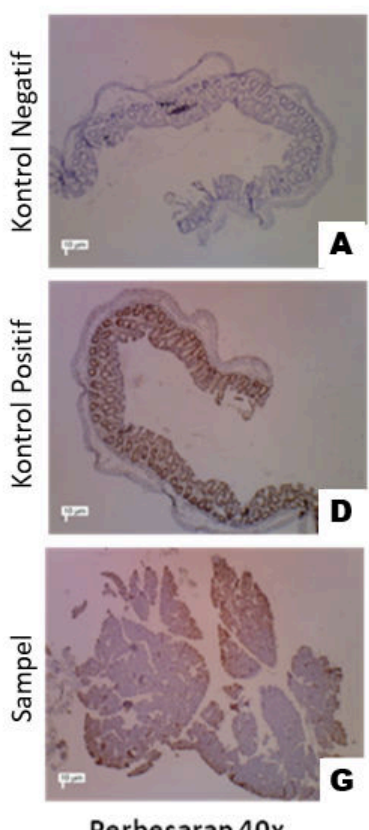

Perbesaran 40x
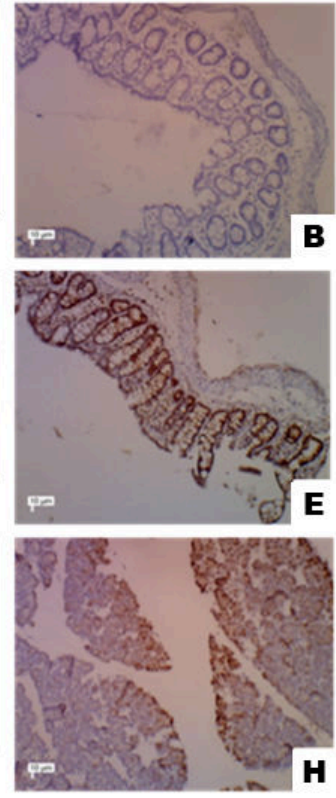

Perbesaran 100x
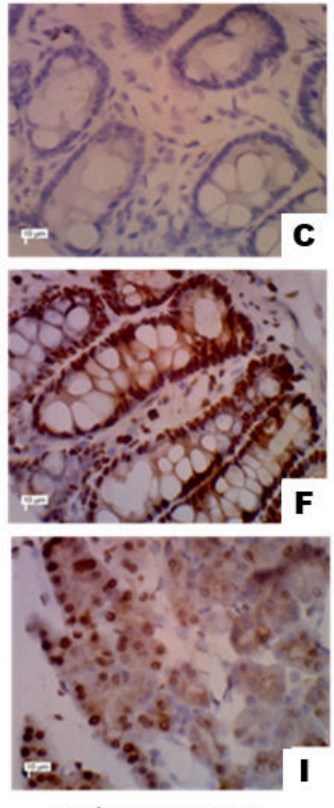

Perbesaran 400x

Gambar 1. Gambaran IHC dengan anti-PCNA (skala 10 $\mu$ m). (A, B \& C) Kontrol negatif menggunakan jaringan Pankreas, tidak tampak adanya proliferasi sel. (D, E \& F) kontrol positif menggunakan jaringan kolon. Tampak selsel positif mengalami proliferasi yang ditandai dengan sel-sel berwarna coklat pada sebagian besar jaringan. (G, $\mathrm{H}$ \& I) sampel jaringan pankreas yang diberikan antibodi PCNA, tampak sel-sel positif mengalami proliferasi hampir pada semua sel. 
Gambar 1. A, B dan C, jaringan pankreas sebagai kontrol negatif hanya diberikan PBS tanpa antibodi anti-PCNA, tidak menunjukkan adannya proliferasi sel (imunonegatif), yang ditandai tidak ada warna atau citra coklat gelap. Hal ini berarti bahwa tidak adanya reaksi antigen-antibodi sehingga pada saat pewarnaan. Gambar 1. D, E dan $\mathrm{F}$, jaringan kontrol positif berupa jaringan kolon yang diberi antibodi anti-PCNA. Menunjukkan aktivitas proliferasi sel ditandai dengan sel-sel yang berwarna coklat gelap (proliferasi sel aktif) yang luas pada jaringan tersebut. Gambar 1. G, H dan I yaitu jaringan sampel menunjukkan penyebaran warna coklat gelap atau proliferasi sel aktif. Jaringan sampel yang diperiksa berupa irisan jaringan pankreas yang diberikan antibodi anti-PCNA. Sel pankreas sampel yang aktif berproliferasi menghasilkan antigen PCNA dan berikatan dengan antibodi antiPCNA. Ikatan ini membentuk reaksi imunologi sehingga dapat diberi label pada antibodi sekunder. Betazoid DAB akan menempel pada antibodi sekunder yang berikatan pada antibodi primer sehingga sel yang aktif berproliferasi berwarna coklat gelap.
Molekul PCNA merupakan stimulator sintesis DNA yang dikatalisis oleh enzim DNA polimerase. Enzim ini bertindak sebagai sliding clamp yang berfungsi sebagai suatu faktor progresivitas. Factor progresivitas ini akan membentuk gulungan yang mampu berinteraksi dengan protein-protein lain yang terlibat dalam replikasi DNA. Satu atau beberapa DNA helikase dan protein pengikat untai tunggal atau singlestranded binding protein (Ssb) yang disebut dengan protein replikasi A atau replication protein $A$ (RP-A) diperlukan untuk memisahkan kedua untai DNA (Wang, 2014). Pada tahap selanjutnya, tiga DNA polimerase yang berbeda terlibat dalam elongasi. Untai pengarah dan masing-masing fragmen untai tertinggal diinisiasi oleh RNA primer dengan bantuan aktivitas primase yang merupakan bagian integral enzim DNA polimerase. Enzim ini akan meneruskan elongasi replikasi tetapi kemudian segera digantikan oleh DNA polimerase pada untai pengarah dan DNA polimerase pada untai tertinggal. Enzim DNA polimerase mempunyai fungsi penyuntingan. Kemampuan DNA polimerase untuk mensintesis DNA yang panjang 
disebabkan oleh adanya antigen PCNA (Maga and Hübscher, 2003; Muskhelishvili et al., 2003).

\section{Gambaran proliferasi sel dengan BrdU}

Penelitian ini diawali penyuntikan 4 kali secara teratur dan dilakukan inkubasi overnight tujuannya untuk lebih mengakumulasikan antigen tersebut sehingga dapat terekspresi dengan baik. Pengamatan dilakukan dengan menggunakan 3 sediaan jaringan histologis yaitu (1) kontrol negatif berupa jaringan pankreas dengan PBS tanpa anti-BrdU, (2) kontrol positif berupa jaringan kolon dengan antibodi anti- BrdU, dan (3) sampel berupa jaringan pankreas dengan antiBrdU. Pewarnaan dengan metode indirect IHC menggunakan antibodi primer (anti- BrdU) dan sekunder (trekki universal link) yang dilabel dengan biotin. Pewarnaan label dengan betazoid DAB memberikan citra coklat gelap seperti yang tampak pada gambar 2 .
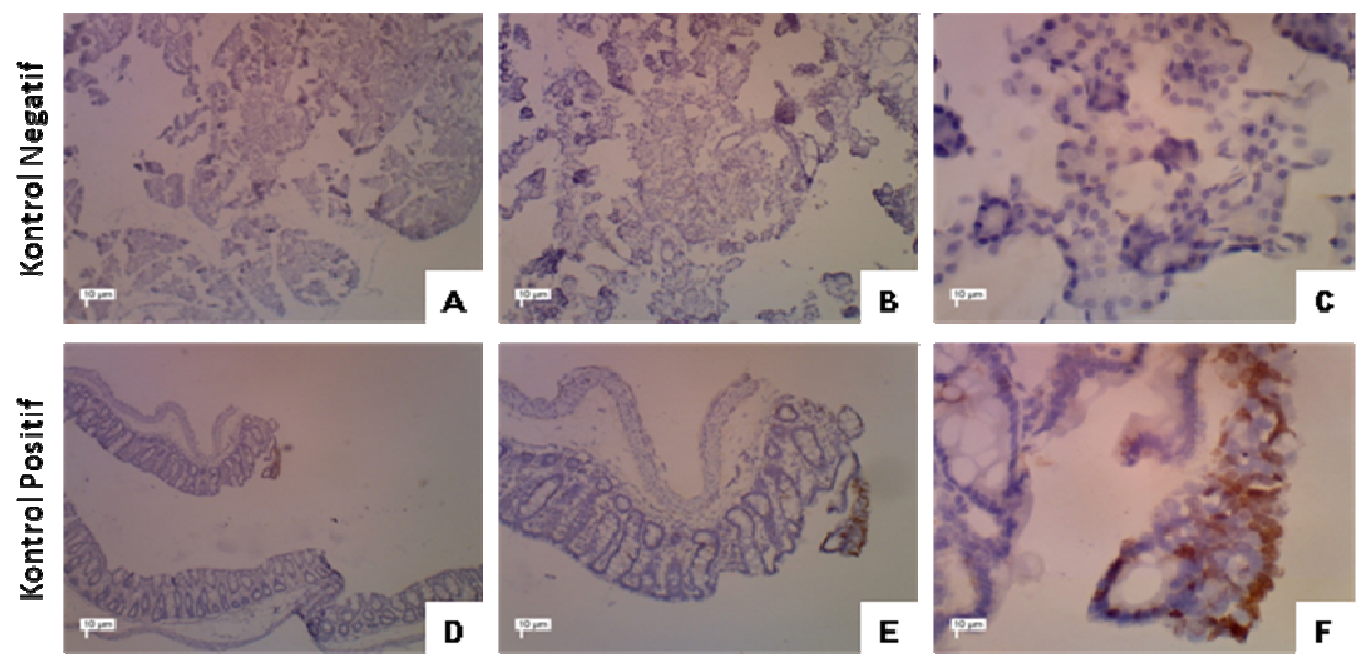

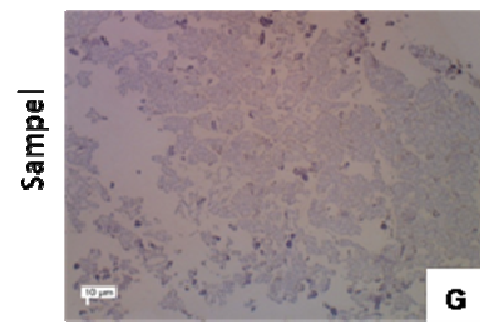

Perbesaran $40 x$

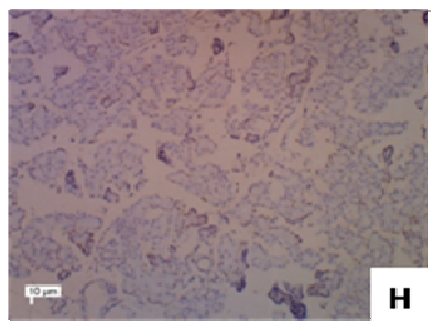

Perbesaran I00x

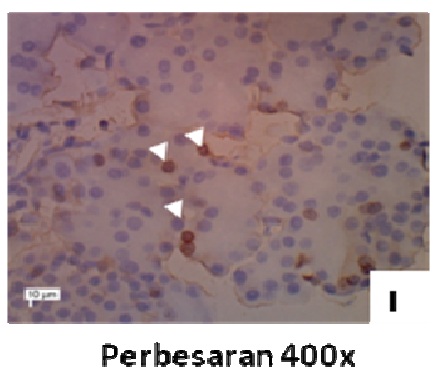

Perbesaran $400 x$

Gambar 2. Gambaran IHC dengan anti-BrdU (skala 10 $\boldsymbol{\mu m}$ ). (A, B \& C) Kontrol negatif menggunakan jaringan Pankreas, tidak tampak adanya proliferasi sel. (D, E \& F) kontrol positif menggunakan jaringan kolon. Tampak selsel positif mengalami proliferasi yang ditandai dengan sel-sel berwarna coklat. $(\mathrm{G}, \mathrm{H} \& \mathrm{I})$ sampel jaringan pankreas yang diberikan antibodi BrdU, pada perbesaran 400x tampak sel-sel positif mengalami proliferasi. 
Gambar 2. A, B dan C, jaringan pankreas sebagai kontrol negatif hanya diberikan PBS tanpa antibodi anti-BrdU, tidak menunjukkan adannya sel yang berproliferasi (imunonegatif), dengan ditandai tidak ada warna atau citra coklat gelap. Gambar 2. D, E dan F, jaringan kontrol positif berupa jaringan kolon yang diberi antibodi antiBrdU. Menunjukkan aktivitas proliferasi sel ditandai dengan sel-sel yang berwarna coklat gelap pada jaringan tersebut. Antigen BrdU diekspresikan oleh sel yang aktif berproliferasi sehingga hasil pengamatan mikroskopis jaringan kontrol positif memberikan warna coklat gelap. Gambar 2. G, H dan I jaringan sampel yang diperiksa berupa irisan jaringan pankreas yang diberikan antibodi anti-BrdU. Sel pankreas sampel yang aktif berproliferasi menghasilkan antigen BrdU dan berikatan dengan antibodi anti- BrdU pada saat pewarnaan IHC. Antigen BrdU diekspresikan oleh sel yang aktif berproliferasi sehingga hasil pengamatan mikroskopis jaringan kontrol positif memberikan warna coklat gelap.
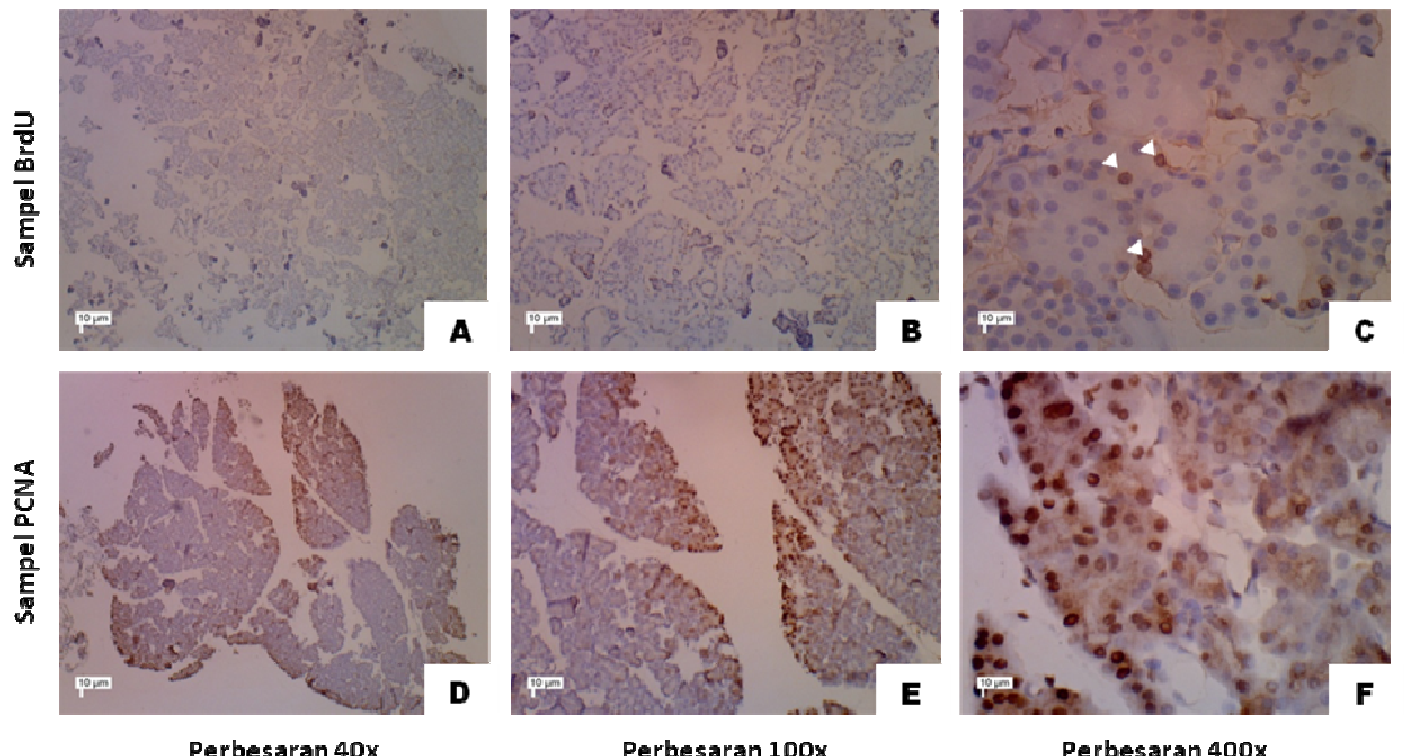

Perbesaran 100x

Perbesaran 400x

Gambar 3. Gambaran histologis pankreas (skala 10 $\mathrm{\mu m}$ ), dengan IHC menggunakan anti-PCNA dan anti BrdU. (A, B, \& C) IHC menggunakan anti-BrdU, dengan perbesaran 400x tampak sedikit sel-sel terwarnai coklat. (D, E \& F) IHC dengan anti-PCNA tampak sel-sel terwarnai coklat yang lebih banyak dibanding dengan BrdU.

Siklus sel dapat dibagi menjadi empat bersiap untuk memasuki fase sintesis (S). Pada tahap presintesis (G1), saat sel-sel tumbuh akan fase S terjadi duplikasi genom (replikasi DNA). 
Pada G2 sel-sel melakukan pemeriksaan apakah replikasi DNA sudah sempurna dan mempersiapkan diri untuk masuk pada fase mitosis (M) dan terjadi proliferasi sel. Setiap fase berada di bawah kendali umum kompleks cyclindependent protein kinases (CDKs). Kompleks CDK-cyclin spesifik: kompleks CDK 4,6-cyclinD mengatur perkembangan melalui G1, Cdk2cyclin-E terlibat dalam mengatur transisi dari G1 ke fase S, Cdk2-cyclin-A dan Cdk1-cyclin-A bekerja pada seluruh fase S, sedangkan Cdk1cyclin-B mengatur proses mitosis. Selain itu, ada mekanisme pemeriksaan khusus yang diaktifkan untuk menghentikan perkembangan siklus sel (Maga and Hübscher, 2003; Cappella et al., 2015, Ahn et al., 2019).

Molekul PCNA dapat membentuk kompleks dengan semua kompleks CDK-cyclin ini sehingga saat dilakukan pengecatan IHC maka akan terekspresi pada setiap fase proliferasi sel (Maga and Hübscher, 2003; Muskhelishvili et al., 2003; Zińczuk et al., 2018). Berbeda dengan BrdU, BrdU diinkorporasi ke dalam DNA sel pada timidin karena merupakan analog timidin. Sel yang telah terinkorporasi dengan BrdU dapat dideteksi menggunakan antibodi monoklonal
BrdU. Analisis hasil dari reaksi inkorporasi BrdU bersifat spesifik untuk menunjukkan keberadaan sel pada fase sintesis (S). Semakin banyak sel mengalami inkorporasi, sel tersebut dominan berada pada fase sintesis DNA (Muskhelishvili et al., 2003; Ota et al., 2016; Wakayama et al., 2014). Itu sebabnya sel-sel positif dengan antiBrdU pada IHC yang dilakukan tampak sedikit yang terekspresi pada inti sel. Berbeda dengan PCNA yang terekspresi pada banyak sel (Wakayama et al., 2014).

\section{SIMPULAN}

Proliferasi sel-sel pankreas dapat terekspresi melalui perwarnaan imunohistokimia dengan menggunakan antibodi anti PCNA dan anti BrdU. Sel yang terekspresi pada BrdU lebih sedikit dibandingkan PCNA. Keduanya dapat digunakan untuk identifikasi sel-sel yang mengalami proliferasi. PCNA akan terekpresi pada semua fase siklus sel sedangkan BrdU spesifik terekspresi pada fase $\mathrm{S}$.

\section{PERSANTUNAN}

Terima kasih kami ucapkan untuk pak Yohanes Suhardi untuk bantuan teknis di laboratorium, dan Departemen Histologi FKKMK UGM atas izin penggunaan laboratorium. 


\section{DAFTAR PUSTAKA}

Albert, B., Bray, D., Hopkin, K., Johnson, A., Lewis, J., Raff, M., Roberts, K., and Walter, P. 2010. Essential Cell Biology 3th edition. Newyork and London. Garland Science.

Ahn, S-H., Granger, A., Rankin, M.M., Lam, C.J., Cox, A.R., Kushner, J.A. 2019. Tamoxifen suppresses pancreatic $\beta$-cell proliferation in mice. PLoS ONE 14(9): e0214829.

Cappella, P., Gasparri, F., Pulici, M., and Moll, J. 2015. CellProliferation Method: Click Chemistry Based on BrdU Coupling forMultiplex Antibody Staining. Curr. Protoc. Cytom. 72:7.34.1-7.34.17.

Kumar, G.L. and Lars, R. 2009. Education Guide; Imunnohistochemical Staining Methods $5^{\text {th }}$ edition. California, USA. Dako.

Kumar, F., Abbas, A.K., Fausto, N., and Aster, J.C. 2014. Tissue renewal, regeneration and repair. Robbins and Cotran pathologic basis of disease $9^{\text {th }}$ edition. Philadelphia. Saunders Elsevier.

Maga, G. and Hübscher, U. 2003. Proliferating cell nuclear antigen (PCNA): a dancer with many partners. J Cell Sci. 116. Pp: 30513060 .

Mescher, A.L. 2013. Junqueira's Basic Histology Text \& Atlas $13^{\text {th }}$ edition. Singapore. McGraw-Hill Companies, Inc.

Muskhelishvili, L., Latendresse, J.R., Kodell, R.L., and Henderson, E.B. 2003. Evaluation of Cell Proliferation in Rat Tissues with BrdU, PCNA, Ki-67(MIB-5)
Immunohistochemistry and In Situ Hybridization for Histone mRNA. $J$ Histochem Cytochem. 51(12). Pp: 16811688.

Ota, S., Nishimura, M., Murakami, Y., Birukawa, N.K., Yoneda, A., Nishita, H., Fujita, R., Sato, Y., Minomi, K., Kajiwara, K., Miyazaki, M., Uchiumi, M., Mikuni, S., Tamura, Y., Mizuguchi, T., Imamura, M., Meguro, M., Kimura, Y., Hirata, K., and Niits, Y. 2016. Involvementof Pancreatic StellateCells inRegenerationof Remnant Pancreasafter Partial Pancreatectomy. PLoSONE. 11(12):e0165747.

Wakayama, T., Nakata, H., Kumchantuek, T., Gewaily, M.S., and Iseki, S. 2014. Identification of 5-Bromo-2'-DeoxyuridineLabeled Cells during Mouse Spermatogenesis by Heat-Induced Antigen Retrieval in Lectin Staining and Immunohistochemistry. $J$ Histochem Cytochem. 63(3). Pp: 190-205.

Wang, S.C. 2014. PCNA: a silent housekeeper or a potential therapeu-tic target?. Trends Pharmacol Sci. 35. Pp: 178-86.

Yin, D.D, You, L.H, Yuan, Q.X., Liang, X.D., Wang, N., Wang, L.T., Yuan, L., Wang, K.M., and De, W. 2014. Mesothelin promotes cell proliferation in the remodeling of neonatal rat pancreas. World $J$ Gastroenterol. 20(22). Pp: 6884-96.

Zińczuk, J., Zaręba, K., Guzińska-Ustymowicz, K., Kędra, B., Kemona, A., and Pryczynicz A. 2018. Expression of chosen cell cycle and proliferation markers in pancreatic intraepithelial neoplasia. Prz Gastroenterol. 13(2). Pp: 118-126. 